reprinted, if not annually, at least at short intervals of years, as furnishing one of the most valuable contributions to economic geology.

H. B.

\section{THE LATE DR. ENGELMANN}

SO many years have elapsed since Dr. Engel$S$ mann, whose death was recently announced in your columns, wrote his academic dissertation "De Antholysi Prodromus, 1832," that it is no matter for surprise if many among the younger generation of botanists have forgotten this little treatise, or have failed to associate its author with the historian of American conifers and other selected orders. This is the less surprising as, although in Dr. Engelmann's systematic memoirs there are frequent traces of his early morphological studies and of the interest he felt in them, he, so far as I know, wrote no treatise specially devoted to teratology other than the one already mentioned. A few words on this little book may therefore not be unacceptable to those who honour Engelmann's memory. It would be an interesting and not an unprofitable task to trace out the connection between teratology and the modern views of evolution, which is mucb closer than is generally imagined, albeit the ideas of natural selection and survival of the fittest find no place in the older teratological literature. For such a task I have neither the requisite ability nor the necessary leisure. My object in alluding to the matter is to call to mind the light in which Engelmann consitered the subject, influenced as he was by the writings of his great fellow-countryman Goethe, whose views, originally published in 1790 , were by no means universally accepted, even in 1832 . Schimper and Alexander Braun were among those who appreciated the value of Goethe's theory, and those two learned men and acute morphologists were Engelmann's teachers, and as we learn from himself, exerted great sway over him.

It is curious to contrast the modest pamphlet "De Antholysi Prodromus," written in Latin, which I at least do not find very easy to construe, with the more elaborate "Élémens de Tératologie Végétale" of Moquin-Tandon, published nearly ten years later (184I). Moquin's work is written in a style which even a foreigner can read with pleasure. Its method, too, is clear and symmetrical, but when we compare the two works from a philosophical point of view, and consider that the one was a mere college essay, while the other was the work of a professed botanist, we must admit that Engelmann's treatise, so far as it goes, affords evidence of deeper insight into the nature and causes of the deviations from the ordinary conformation of plants than does that of Moquin. A fe illustrations will suffice to make this clear. Speaking of pro. gressive development, or as he calls it " $e$ "volutionis progressus," Engelinann says that while it is only obscurely indicated in celestial bodies, and with difficulty studied in animals, "clarissine apparet in plantis." Plant-history is for Engelmann the narrative of the progress of evolution-" evolutio progrectiens"-and variations from the ordinary course are to be accounted for, "ex nimio motu, et ex nimio impeditione," or, as we should now say, from excess or from arrest of development.

The main end of a plant is to produce seed, and the morphology of the plant appears to have been considered by Engelmann as the result of a compromise between this tendency (nisus) and the progresive development of each individual part. The morpho'ogical unit for him, as for Goethe, from whom he derived the notion, was the leaf.-." unitas autem in foliis posita est"-and the variations from the leaf-type were, as we have seen, attributed to arrest of development, to reversion (regressus), or to progression. But these changes were looked upon then chiefly in relation to the greater or less development and specialisation of individual parts with little or no reference to their possible genealogical significance as elements in a general pedigree of plants, or at any rate as suggestive of such elements. Hereditary influence, however, was not wholly overlooked; on the contrary, Engelmann speaks of it as "magni momenti," and goes on to show how woody plants frequently show, year after year, the same malformations, how perennial plants less frequently do so, and how such repetition is much less frequently observable in annuals and plants propagated wholly by seed. Only "antholyses cpiphytice hereditaria esse possunt" (\$69), says our author, by which he means that partial changes are not perpetuated by descent, but only those in which "omnes plurimive flores morbosi sunt." It is not necessary to stop to consider what amount of truth there is in this assertion, but it is interesting to see the use then made of the word "epiphyte." Engelmann influenced by his medical studies, spoke of "local," "epiphytical," "sporadic," "enchoric," and "enchronic" affections; enchoric changes being limited to certain localities, enchronic alterations occurring at definite times. These terms have not been generally adopted, while the signification now attached to the word "epiphyte" is widely different from that which Engelmann intended. He, at least, had not the right of priority in this matter, for Bischoff, in his "Botanische Terminologie" (1830), speaks of epiphytes as external parasites (citing as examples Cuscuta and Viscum), in contradistinction to entophytes. It would seem from this that in matters of terminology custom overrides priority. But this by the way. Our present concern is with the fact that certain changes, or certain degrees of change, are more likely to be perpetuated than others. Similarly we find Engelmann calling attention to certain "critical" regions of the plant,-spots, that is, more subject than others to teratological change, - the apex of the stem in definite inflorescences for instance $(\$ 67)$, a point subsequently dwelt on by Darwin at so.ne length, though he does not seem to have been aware of what Engelmann had previously written on the subject.

Lastly, reference may be made to the assertion made by Engelmann that plants of a high state of relative structural perfection "structurat magis evolutâ et typo magis composito," are specially liable to retrograde metamorpbis. This is a statement that from the nature of things seems so reasonable that it is generally accepted without question. Nevertheless, it is one which requires qualification and further investigation. To take one case which occurs at the moment. Let any observer call to mind the number of instances in which he has seen the carpels the subjects of retroyrade metamorphosis, and he will probably find that such changes are far more common in cases where the carpels are free and superior, than in those in which they are in union one with another and with the thalamus, as in the so-called inferior ovaries, which are considered to represent a higher type of structure than do the free carpels.

But the object of this note is not to discuss any particular view that Engelmann may have held, but merely to call attention to his claims as a morphologist, claims which are overlooked by reason of his greater-numerically greater--claims as a systematist.

\section{MAXWEll T. MASTers}

\section{SIWALIK CARNIVORA ${ }^{1}$}

$\mathrm{BY}$ the publication of the present memoir on the Siwalik and Narbada Carnivora, Mr. Lydekker completes the second volume of the series of the "Palæontologia Indica " devoted to the Indian Tertiary and Post-Tertiary

I "Palæ untol gia Indica," Series x. Indian Tertiary and Post-Tertiary Vertebrata, Vul. ii. Part 6. Siwalik and Narbada Carnivora. By R. Lydekker, B.A., F.G.S., F.Z.S. Fublished by order of His Excellency the Governor-General of India in Council. (Calcutta, 1884.) 
Vertebrat. Both these volumes, it may be remarked, treat of mammalian forms, and, with the exception of a memoir on Rhinociros deccanensis, by Mr. R. B. Foote, are fr $) \mathrm{m}$ the pen of Mr. Lydekker. Each volume contains about 300 pages and forty-five plates.

No traces of mammals have yet, it would appear, been detected below the Eocene in India, and even in this formation only some very fragmentary bones have been obtained from the Punjab. From the Miocene the remains of a rhinoceros have been found. In the Pliocene mammalian remains begin to be pretty numerous. Thirtythree species of Carnivora from Siwalik are described in the present memoir; they belong to the following families: Mustelidæ, Ursidæ, Viverridæ, Hyænidæ, Felidæ, and Hyænodontidæ. Of the first of these families, two species of the genus Mellivora are described; one of these, $M$. sivalensis, was first noticed in the supplemental plates of the "Fauna Antiqua Sivalensis," and the original is in the British Museum. A second skull and the ramus of a mandible are in the Science and Art Museum, Dublin. The annexed woodcut shows the right side (Fig. I, $a$ ) of the palite of this latter. The original describers of these

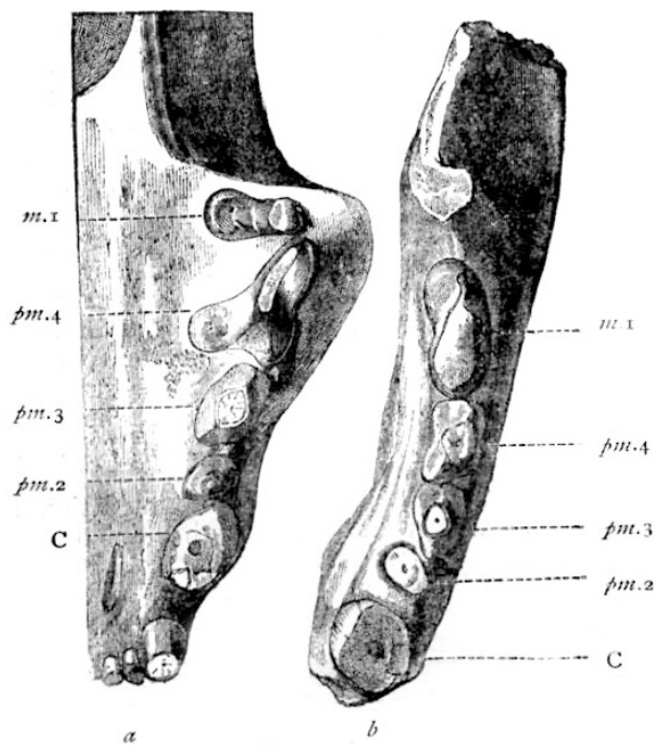

FIG. I,-Meliziora sizalensis (F. and $\mathrm{C}$ ). The right half of the palate (a) and the left ramus of the mandible $(b)$. Natural size.

specimens, Colonels Sir W. Baker and Sir H. Durand, remark on their close affinity to the recent Mellivora indica, and Mr. Lydekker says that in most respects the forms of the recent and fossil jaw's are exceedingly alike. In the fossils the $p m .2$ and $\not m .3$ are slightly larger in the upper jaw than in the recent form, and the true molar (m.1) of the former differs from that of the latter by being much less expanded at its inner extremity. In the mandible (Fig. $1, b$ ) there is not much difference between the fossil and recent forms. The difference, however, between the extinct and recent Indian ratel may be summed up as being about the same in degree as between the recent Indian and African forms, leaving it probable that India may have been the original home of the genus. A second species is described as new, M. punjabiensis. A new genus (Mellivorodon) is formed for a form intermediate in size between the ratel and the glutton, while the form and relative proportions of its teeth indicate that it was more nearly allied to the former than to the latter. Two species of Lutra, L. palceindica, F. and C., and L. sivalensis, $F$. and $C$., are described from the region of the typical Siwalik Hilis in the neighbourhood of the
Ganges and Jumna Valleys, and one, L.bathygnathus, Lyd., from the Siwaliks of the Punjab; this last is of extreme interest, as, while presenting no sort of affinity to any of the existing Indian species, it is most closely allied to the recent South African otter ( $L$. lalandi), and thus affords another well-marked example of the intimate connection of the Tertiary mammalian fauna of India with the present African fauna.

The evidence of the close relationship of the bears and the dogs appears to Mr. Lydekker too strong to refer them, at all events for palæontological purposes, to separate families. We therefore have the Ursidæ comprehending the two modern families Ursidæ and Canidæ, these being formed into groups as Ursinæ and Caninæ. The author does not, however, attempt to form a definition of the family as thus extended, nor is he even quite certain as to the limits of the sub-groups. Of the species described, one, $U$. namadicus, F. and C., is from the Pleistocene Narbada beds; the other, $U$. theobaldi, Lyd., was obtained by Mr. Theobald from the Siwaliks of the Kangra district. It would seem to be nearly related to the recent $U$. labiatus, which itself seems to stand quite isolated from all the other recent bears, its strangely

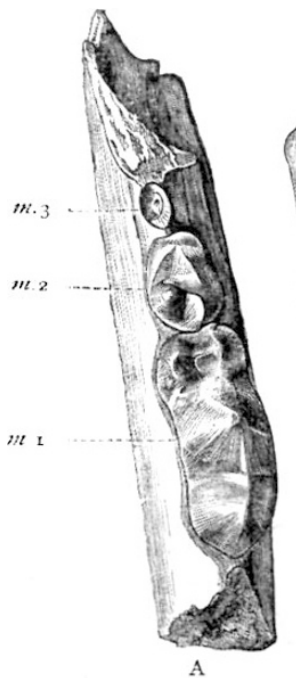

A

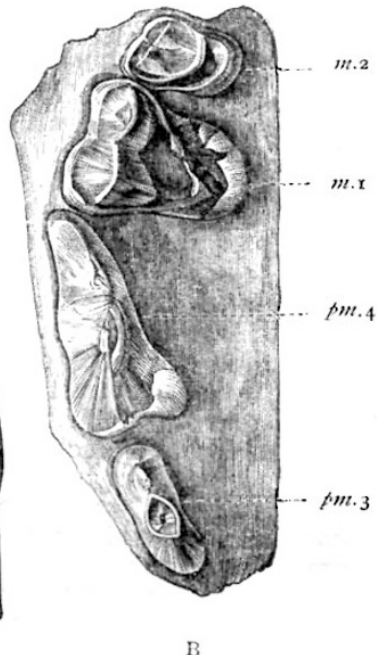

FIC. 2.-Canis cautleyi (Bose). Part of the left ramus of the mandible (A) and the left side of the palate $(B)$

modified molar dentition being the result of the nature of its food. Three species of $H$ yanarctos are mentioned: $H$. sizualensis, F. and C., H. punjubiensis, Lyd., and $H$. palaindicus, Lyd. The line of descent of the genus is thought to be from the bears, through Dinocyon, to the true dogs. Amphicyon palceindicus, Lid., is redescribed and refigured; it approaches $A$. intermedizs, Myr., described from the Miocene of Bohemia on the eastern side of Europe. Of the genus Canis the following are described :-C. urvipalatus, Bose, and $C$. cautleyi, Bose. The occurrence of this latter species in the Siwaliks is one " of extreme importance in regard to the Pliocene age of at least a large portion of those deposits, for in the Tertiaries of Europe, with which the Siwaliks are in many respects closely allied, true wolves are unknown before the Pliocene." Among the Siwalik fossils in the Science and Arr Museum, Dublin, there is an associated portion of the skull and two fragments of the mandible of this wolf, portions of which are represented in the woodcut (Fig. 2 ). In A are shown $m .1$ and $m .2$ in a very perfect and almost unworn condition, and also the broken fang of $m \cdot 3$. In $B$ the left side of the palate shows the canine and the earlier premolar. 
Of the Viverridæe we find the following:-Viverra bakeri, Bose, and $V$. durandi, Lyd. Of the Hyænidæ four species of Hyæna are described, based on specimens in the collections of the British, Indian, and Dublin Museums, and there are not wanting evidences of a fifth form. It is remarkable to find so many species of byæna existing contemporaneously in India ; but, when the large number of Proboscidia and other ungulate forms that existed at the same time is recalled to memory, to find the genera of Carnivora equally strongly represented in species is perhaps only what might have been expected. The earliest notice of the remains of Hyæna from the Siwaliks appeared in 1835 in the Journal of the Asiatic Society of Bengal, where Sir W. L. Baker described a specimen as "the most perfect fossil we have yet been so fortunate as to meet with." This specimen is figured in the annexed woodcut (Fig. 3), and is at present in the Dublin Museum. The species has been described by Mr. Bose as $H$. felina. Its affinities are towards the recent $H$. crocata of South Africa, a species common in Europe during the Pleistocene period; and this fact points, Mr. Lydekker thinks, to the conclusion that Asia rather than Africa may be regarded as the cradle of the race of hyænas. H. colvini, Lyd., H. macrostoma, Lyd, the latter a species that seems to constitute an important link between the more typical members of the genus and the viverroid and canoid Carnivora. H. sivalensis, Bose, is redescribed and figured. A new genus, Lepthyæna, is made for a species previously recorded as Ictitherium sivalense. The Siwalik Felidæ embrace Aluiopsis annectans, Lyd., a new genus and species of which but little is known; AElurogale sivalensis, Lyd., for a carnivore intermediate in size between the Thibetan lynx and the leopard. Six species of Felis are either described or indicated ; of those described are $F$. cristata, F. and C., $F$. brachygnathus, Lyd., and $F$. subhimalayana, Bronn. Of the genus Machærodus two species are included in the list of Siwalik forms. M. sivalensis, F. and C. : a

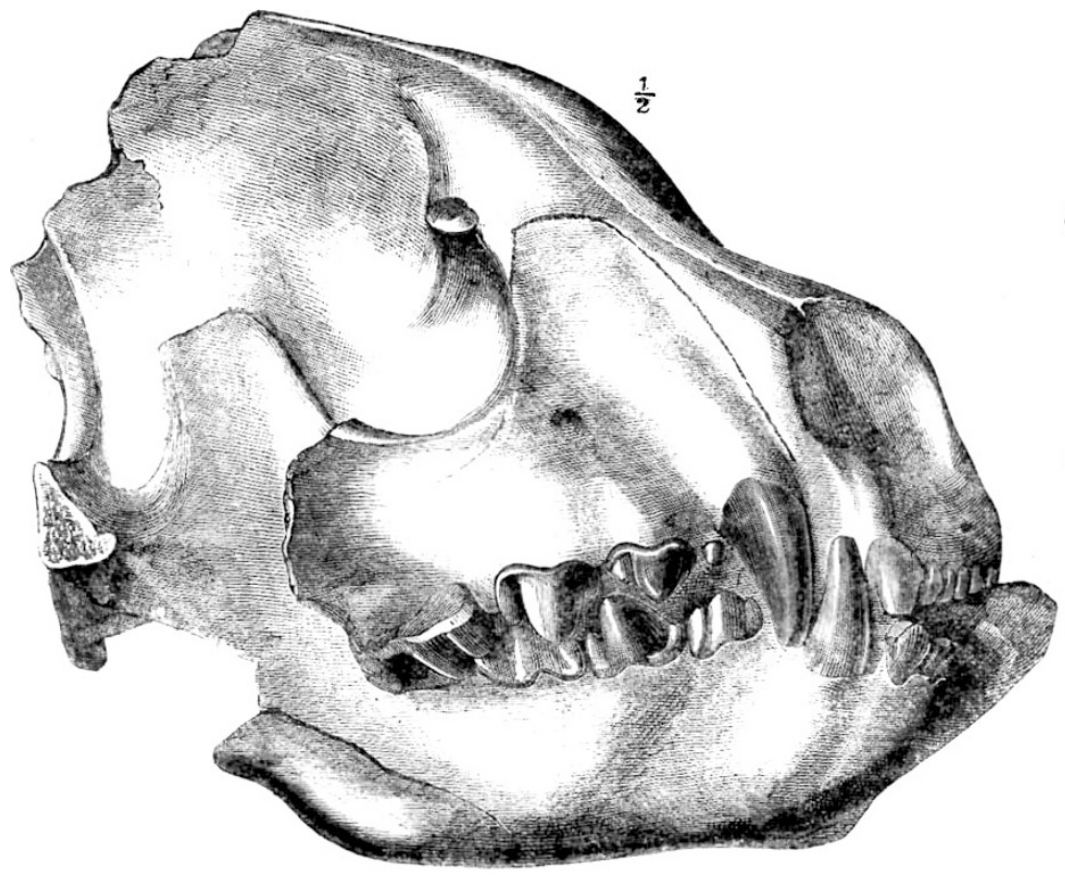

A

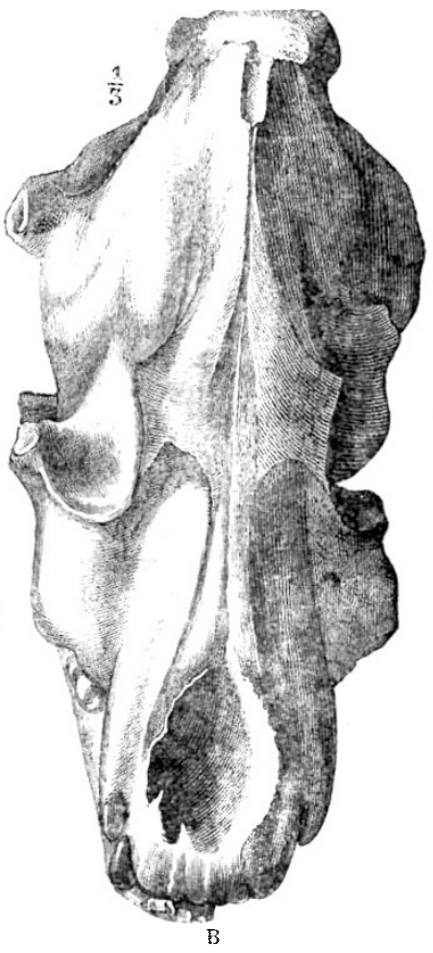

B

Fic. 3.-Hycena felina (Bose), A, oblique view of right side of cranium; , front view.

nearly complete left ramus of the mandible of this species is in the Dublin Museum, and is represented in Fig. 4 ; posteriorly it is complete, with the exception of the coronoid process, while anteriorly it is broken through the symphysis; it shows part of the alveolus of the canine and the greater portion of the descending expansion. The three cheek teeth are preserved, but in a more or less broken condition; a large part of the outer surfaces of pm.4 and m.I have been chipped away. These teeth agree with the type specimen in the British Museum, with the exception that p1li.3, though still small, is inserted by two distinct fangs. The last family, that of Hyænodontidæ, is one conjidered by Prof. Huxley as occupying a position connecting the Carnivora with the Insectivora. Only one species belonging to the genus Hyænodon has been found. This genus has hitherto only been recorded from Europe and Norh America. The species $H$. indicus, Lyd., is represented by teeth from the Siwaliks of Kúshalghar and the Punjab.

Perhaps the most striking feature in this list of extinct forms is the fact that by the side of ratels, bears, jackals, and civets, some hardly to be distinguished from living species, there are to be found essentially primitive forms,

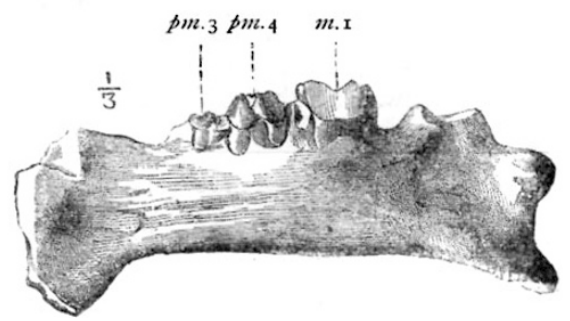

FIG. 4-Macharodus sivalensis (F. \& C.). Outer view of left ramus of mandible of a male.

proving the survival in India of old types long after they had disappeared from other parts of the world. Equally noteworthy is the apparently contemporaneous existence 
of specialised and generalised forms of the same genus; this is well seen in the hyæna. It will also be seen that the Siwalik carnivorous fauna fill up many gaps in the chains of relationship, such as that between the bears and dogs, the viverroids and hyænas, and these latter and the cats.

The rock series in which these fossils occur is therefore one of very great interest. From the Brahmaputra to the Jhelum, for a distance of I 500 miles along the base of the Himalayas, tbere extends with varying width a succession of ridges or ranges which are known as the sub-Himalayan hills. Physicaliy and constitutionally they are readily distinguished from the ranges belonging to the mass of the Himalayas proper. The rocks forming them are all of Tertiary age, and they are divisible into an upper (the Siwalik) and a lower (the Sirmur) series; these again are further divisible respectively into upper, middle, and lower groups. This is the principal and classic area of these rocks, but they occur also in Burmah, Perim Island, and in Sind.

With the Sirmur series, which in part consists of marine (Nummulitic) strata, we have no special concern at present. It is from the rocks of the Siwalik series alone that the vast harvest of remains of fossil vertebrates has been collected in the sub-Himalayan region during the past fifty years. The fossil-bearing beds are principally conglomerates of undoubtedly fresh-water origin, indeed, owing to their local development at the gorges of the existing great rivers, where they emerge from the Himalayas, it is clear that they were deposited at a time when, so far, the configuration had been established; but, as the very highest beds exhibit signs of intense disturbance and crushing, it is no less apparent that, although the main drainage lines have not altered, there has been much movement and upheaval, which, however, appears to bave been effected, not by sudden, but rather by slow and gradual action.

After much discussion as to the correlation of the se fossiliferous conglomerates with the established order of sequence in Furope, it would apfear to have been finally adopted that, in spite of a certain Miocene facies in the fauna, the general characteristics are such as to indicate a Pliocene age. Fossil-bearing beds of Post-Pliocene age occur, it may be here remarked, in other parts of India.

Numerous and varied as the fossils from these rocks are which are now preserved in the museums of Calcutta, London, Dublin, and elsewhere, they do not appear to be found anywhere concentrated in great quantities, the specimens having for the most part been found at widely separated intervals, where they lay more or less weathered out of the enveloping matrix. Though naturally mineralised, and with but a small percentage of residual animal matter, they are often beautifully preserved, but occasionally, owing to the hardness and tenacity of the matrix, it has required the utmost patience and skill to chisel out the details of structure, while sometimes it has been found impossible to do so.

Mr. Lydekker is to be warmly corgratulated on the completion of this important volume, and we are giad to know that he is busy with volume iii., which is to include an account of the Siwalik Suina and Birds.

\section{AN EARTHQUAKE IN ENGLAND}

$A T$ last the people of these islands bave been enabled to realise the meaning of the term " earthquake," so terrible in its significance in many ot her parts of the globe. On Tuesday morning, at a time variously given from 9.1 5 to 9.30, a shock which was really alarming and did considerable damage was felt over the Eastern Counties and as far west as Londion and even Rugby. The centre of disturbance seems to bave been at Colchester, and the wave apparently travelled from south-east to north-west, though impressions vary on this point. A Colchester, in addition to the undulations of the earth, subterranean rumblings were heard, buildings rocked to and fro, the streets were strewn with debris of fallen chimneys, a chapel spire was thrown to the ground, and other signs of seismic disturbance were evident, familiar enough to those who have been in countries where such phenomena are common occurrences. The shock, when it was most intense, commenced with a rumbling sound, increasing in inten ity for about twenty seconds, and then suddenly stopped. It extended to Chelmsford, Cambridge, Northampton, Ipswich, Sudbury, Rugby, Leicestershire ; it included London and the surrounding district in its sweep, and even caused some alarm in the Strand. At Woolwich it was so strong that some persons attributed the shock and noise to the bursting of a heavy gun.

We have received the following communications with reference to the earthquake :-

ONE of the most severe earthquake shocks which has occurred in England for many years took place this (Tuesday) morning in the Eastern Counties. The area of its chief operation lay over South Suffolk and North Essex, and the principal focus of the disturbance seems to have been the neighbourhood of Colchester. A great deal of harm has been done to property there : houses are partially unroofed, many chimneys and gable-ends of the very old houses in Colchester have been demolished, part of the spire of the Lion Walk Congregational Chapel (a well-know $n$ building), to the amount of twenty feet from the apex, was thrown down, and other details of mischief done are fast coming in. Langenhoe Church, about twenty-four miles from Colchester, is said to be all but demolished, the entire eastern end being shaken down. The Rectory also severely suffered, so that little more than the walls are standing. At Wyvenhoe, near Colchester, the church steeple is thrown down and many houses are much damaged. Other villages around Colchester have more or less suffered: Lexden, Abberton, Greenstead, Hythe, \&c., all show evidences of the disturbance in their more or less shattered buildings. The shock was severely felt here at Ipswich. I was sitting down at 9.18 a.m. when the first shock occurred, and it nearly overbalanced me. I felt it must be an earthquake oscillation, although I had never experienced anything like it before, and accordingly waited and watched for the next. The oscillations followed each other for about three seconds, and apparently travelled in a north-north-easterly direction. I underwent quite a new experience, so vivid that I am not likely to forget it. The sensation approached that of nausea. In the town of Ipswich many people were alarmed, for the bells were set ringing, the pictures on the walls shaking, \&c. The occurrence is too recent, however, to carefully note the direction of the oscillations. The London Clay in Suffolk and North Essex, when cut into, abounds with small faults and creeps, and this shock may be leaving another such token behind it.

Museum, Ips wich, April 22

AT about 9.20 this morning I distinctly felt a slight earthquake. The motion though slight was unmistakable, the chair on which I sat, and the whole house, seemed to move to and fro for the space of, as near as I could judge, ten seconds. I regret I cannot give the exact time when I felt the shock, as I had omitted to put my watch in my pocket.

Rugby, Tuesday, April 22

THIs morning the earthquake was very perceptible here at exactly 9.22. It was travelling from north to south in short rapid undulations. It lasted for thirty-tbree seconds. My chief object in writing is to draw attention to the fact that this is the second earthquake which has shaken 